СИНЕРГЕТИЧНИЙ ПІДХІД ЯК МЕТОДОЛОГІЧНА ОСНОВА ДОСЛІДЖЕННЯ СИСТЕМИ ПРОФЕСІЙНОЇ ПІДГОТОВКИ МАЙБУТНІХ МАГІСТРІВ ПОЧАТКОВОЇ ОСВІТИ ДО ІННОВАЦІЙНОЇ ДІЯЛЬНОСТІ

\title{
SYNERGETIC APPROACH AS A METHODOLOGICAL BASIS OF RESEARCH OF THE PROFESSIONAL TRAINING SYSTEM FOR FUTURE MASTER'S OF ELEMENTARY EDUCATION TO INNOVATIVE ACTIVITIES
}

Стаття присвячена аналізу процесу професійної підготовки майбутніх магістрів початкової освіти до інноваційної діяльності в аспекті синергетичного підходу. Зокрема, здійснено синтез тезаурусу та літературних джерел з досліджуваної проблеми. Розкрито сутність синергетичного підходу. З'ясовано, що синергетичний підхід пояснює систему профресійної підготовки як таку, що самоорганізовується та забезпечує иілісність змісту професійної освіти майбутніх фрахівців освітнього рівня «Магістр» за рахунок формування ґрунтовної відкритої системи знань і умінь, які не лише ефрективно використовуються у професійній діяльності, але й оперативно перебудовуються та оновлюються відповідно до змін у сучасній науці. Запропоновано основні вимоги до професійної підготовки майбутніх магістрів початкової освіти до інноваційної діяльності з урахуванням основних положень синергетичного підходу, а саме: прочес професійної підготовки має бути відкритою системою, тобто складатися з підсистем, між якими відбувається обмін інформацією; необхідно збагачувати навчальний процес синергетичними методами навчання, такими як: самоосвіта, стимулююче навчання, нелінійний діалог учасників освітнього процесу, навчання як адаптивна модифрікація, які сприятимуть формуванню світоглядних, методологічних і синергетичних знань і умінь; ЗВО мають створити умови не лише для забезпечення майбутнього срахівця грунтовними професійними знаннями, навичками для формування його світогляду на основі сучасно наукової картини світу, а й розвитку самостійного, критичного, творчого мислення, умінь і навичок контролю, прогнозування, своєчасного прийняття обгрунтованих рішень, а головне - сприяти соціальній самореалізації особистості. Також виділено основні шляхи реалізації синергетичного підходу у професійній підготовці майбутніх педагогів. Зроблено висновки, що використання синергетичного підходу у прооресійній підготовиі майбутніх магістрів початкової освіти до інноваційної діяльності сприяє збагаченню освітнього процесу закладів вищої освіти діалоговими прийомами і методами педагогічної взаємодії, що інтенсифрікує процес особистіснопрофресійного зростання майбутніх педагогів та фрормує їхню готовність до інноваційної діяльності.

Ключові слова: професійна підготовка, майбутні магістри початкової освіти, інно- ваційна діяльність, синергетичний підхід, методологія підготовки.

The article is devoted to the analysis of professional preparation of future masters of elementary education to innovative activity in the aspect of synergetic approach. In particular, thesaurus and literature sources were analyzed within the problem under study. The essence of the synergistic approach is revealed. It has been found out that the synergistic approach explains the system of vocational training to be self-organizing and to ensure the content integrity of professional education of future specialists of educational level "Master" by forming a thorough open system of knowledge and skills, which are not only effectively used in professional activities, but also are quickly rebuilt and updated with changes in modern science.

The basic requirements for the professional preparation of future masters of elementary education to innovative activity are offered, taking into account the basic provisions of the synergistic approach, namely: the training process must be an open system, that is, consist of sub-systems between which information is exchanged; it is necessary to enrich the educational process with synergetic teaching methods, such as: self-education, stimulating learning non-linear dialogue of participants in the educational process, learning as adaptive modification, which will contribute to the formation of ideological, methodological and synergistic knowledge and skills; higher education institutes must create conditions not only for providing the future specialist with thorough professional knowledge, skills for forming their outlook on the basis of the modern scientific picture of the world, but also for developing independent, critical, creative thinking, skills for controlling, forecasting, making timely grounded decisions in oder to promote the social self-realization of the individual. The main ways of implementing the synergistic approach in the future teachers' professional training are also highlighted. It is concluded that the use of a synergistic approach in the professional preparation of future masters of elementary education to innovative activities contributes to the enrichment of the educational process of institutions of higher education through dialogues and methods of pedagogical interaction, which intensifies the process of personal and professional growth of future teachers and shapes their readiness to innovative activity.

Key words: vocational training, future masters of elementary education, innovative activity, synergetics, synergistic approach, training methodology.
Постановка проблеми у загальному вигляді. Нові цивілізаційні виклики, зумовлені розвитком науки та інформаційних технологій, інноваційні зміни, які нині відбуваються у вищій освіті, актуа- лізують проблему професійної підготовки майбутніх педагогів, зокрема майбутніх магістрів початкової освіти, до інноваційної діяльності. Фахівець, який працюватиме із сучасною молоддю, має бути 
насамперед людиною 3 багатогранними інтересами, запитами, прагненнями; знати іноземні мови; слідкувати за інноваціями в освіті та науці. Тому нові завдання для освіти й педагогічної науки не можуть реалізовуватися старими засобами, а сучасна фрілософія освіти має запропонувати нові засади, на яких базуватиметься освітньо-педагогічна діяльність 3 формування людини креативної, яка найбільшою мірою відповідатиме запитам інноваційного простору.

У Всесвітній декларації про вищу освіту для XXI століття сорормульовано необхідність нового бачення парадигми вищої освіти, орієнтованої на того, хто навчається, а також нового бачення в «парадигмі її змісту, методів, практики і засобів забезпечення на основі нових видів зв'язків і партнерства зі спільнотою і самими широкими верстами населення» [1]. У документі зазначається, що заклади вищої освіти мають забезпечувати таку освіту студентам, яка виховуватиме добре поінформованих та глибоко мотивованих громадян, здатних до критичного мислення, аналізу суспільної проблематики, пошуку та вирішення проблем, які постають перед суспільством, а також уміння брати на себе соціальну відповідальність. Тому модернізація професійної підготовки таких фрахівців потребує методологічного підґрунтя.

Аналіз останніх досліджень і публікацій. Окремі методологічні підходи в організації освітнього процесу у закладах вищої освіти були предметом дослідження українських науковців. Синергетичний підхід як інноваційна методологія педагогічної освіти знайшов своє відображення в дослідженнях О. Вознюк, О. Дубасенюк, О. Іонова, І. Зязюна, В. Кременя, С. Кузікової, В. Мельникова, Я. Москальової, Л. Ткаченко, Т. Тюріної, О. Робуль та ін.

Виділення не вирішених раніше частин загальної проблеми. Актуальність і проблемність упровадження ідей синергетики в освіту, що зумовлюється наявністю в освітянській практиці як традиційного лінійного, так і нелінійного імовірнісного синергетичного мислення, випливає із певних протиріч у освітянській практиці: необхідності реалізації синергетичного підходу у професійній діяльності сучасного педагога та недостатньої розробленості в педагогічній теорії вихідних концептуальних засад педагогічної синергетики у процесі профресійної підготовки майбутніх магістрів початкової освіти до інноваційної діяльності.

Мета статті - розкрити сутність синергетичного підходу, виявити можливості його застосування у професійній підготовці майбутніх магістрів початкової освіти до інноваційної діяльності, з'ясувати доцільність застосування цього підходу та виокремити шляхи його реалізації.

Виклад основного матеріалу. Усвідомлення природи сучасної інноваційної діяльності людини значною мірою залежить від глибини розуміння сутності існування цивілізації і формування постнекласичної науки. Усвідомлення того, що людство входить у нову сучасність, в епоху становлення глобального світу, в якому невпинно розширюються взаємозв'язки і взаємозалежність індивідів, держав, націй, утворило принципово нову науково-технологічну, соціальну і культурну основу суспільного буття. Уявити універсальну єдність нового світу дає змогу синергетика, яка підводить до можливості наочно проілюструвати єдність у різноманітності і різноманітність у єдності.

Синергетичний підхід склався недавно та з успіхом використовується у дослідженні освітніх процесів. Термін «синергетика» (грец. sinergos спільна дія, співробітництво) означає сприяння, співпраця.

У фрілософському словнику зазначається, що синергетика - сучасна теорія самоорганізації, нове світобачення, що пов'язується 3 дослідженням френоменів самоорганізації, нелінійності, неврівноваженості, глобальної еволюції, з вивченням процесів становлення «порядку через хаос» (І. Пригожин), біфукарційних змін, незворотності часу, нестійкості як основної характеристики процесів еволюції [7, с. 618].

Загальновідомо, що синергетика - наука про взаємодію в системах різної природи та самоорганізацію складних систем - виникнення нових якостей в цілому, що складається із взаємодіючих об'єктів [9, с. 811-812]. Синергетика як один із новітніх наукових напрямів може вважатися провідною галуззю міждисциплінарних досліджень, що поширюються на всі сорери суспільного буття. Синергетика охоплює теорію виникнення нових якостей в цілому, що складається із взаємодіючих об'єктів (теорія самоорганізації складних систем) і міждисциплінарного підходу на основі співробітництва спеціалістів різних галузей.

Засновником синергетики вважається німецький учений Г. Хакен [12], котрий уперше ввів це поняття в книзі «Синергетика». Згодом стали з'являтися й інші праці, до прикладу, «Самоорганізація і культура» А. Свідзинського [10], в якій для вивчення такого складного процесу, як культура, використано методи синергетики. Появлення синергетики, на думку її засновників, є ще одним кроком уперед сучасної науки. «Нині, зазначає І. Пригожин, - коли фрізика намагається конструктивно включити нестабільність до картини універсума, спостерігається зближення внутрішнього і зовнішнього світів, що, можливо, $€$ однією з найважливіших культурних подій нашого часу» [8, с. 45-57].

Проаналізувавши думки багатьох учених, визначаємо, що синергетичний підхід розкриває суттєво нові діалектичні принципи взаємодії таких протилежних начал, як: упорядкування і хаос, ста- 
лість і змінність, передбачуваність і непередбачуваність тощо. Окрім того, такий підхід приводить до нового діалогу людини із самою собою та з іншими людьми, розвиваючи людські схильності до компромісів, толерантності, відповідальності перед майбутнім. Ідеї синергетики знаходять широке застосування в освітньому просторі, коли педагогічні системи починають аналізуватися в термінах синергетичної теорії самоорганізації.

Національна стратегія розвитку освіти передбачає врахування синергетичного підходу як інновацію, що полягає у взаємодоповненні суміжних середовищ: особистісного, етнокультурного та інформаційно-освітнього середовища навчального закладу [6, с. 28].

Науковці І. Кудрявцева та С. Лєбєдєва синергетичну систему характеризують як здатність утворювати множинність структур, що виникають, параметри яких визначаються властивостями самої системи і характером взаємодії з навколишнім середовищем. Саме це визначає здатність цих систем до еволюції - послідовної зміни структур у процесі розвитку [5, с. 55-63].

Основоположною складовою частиною синергетичної парадигми в педагогіці є принцип самоорганізації складної системи, зазначає Л. Ткаченко [11, с. 18-21]. На думку В. Кременя, «педагогічна синергетика дає можливість по-новому підійти до розроблення проблем розвитку педагогічних систем і педагогічного процесу, розглядаючи їх насамперед з позиції відкритості, співтворчості та орієнтації на саморозвиток» [4, с. 4-9]. «Синергетика як методологічна парадигма безпосередньо стосується фрілососрії людиноцентризму, яка є виміром сучасної людини. Це означає, що в умовах сучасного інформаційного світу <...> недоцільно користуватися старими методами і моделями, оскільки вони використовуються як базисні методи лінійного мислення й лінійних «наближень» [3, с. 279].

На думку академіка І. Зязюна, синергетика дає розгорнуте уявлення про те, як з хаосу виникає впорядкована складність. Дослідник підводить читача до бачення універсальної єдності світу, дає змогу наочно проілюструвати єдність у різноманітності і різноманітність у єдності. Синергетика допомогла науковому співтовариству усвідомити нелінійність, багатофракторність та ймовірність реального світу, поліваріантність шляхів його розвитку і неможливість описання цього в межах класичних теорій і моделей з їх лінійним уявленням про розвиток і самоорганізацію. Це та єдина процесуальна модель світу - синергетична, через призму якої світ є ієрархією взаємодіючих систем, в якій все нежива й жива природа, суспільство й культура, життя й творчість людини-взаємопов'язані й підпорядковані єдиним вселенським законам [2, с. 608].

У використанні синергетики в освіті І. Зязюн виокремлює три важливі складники: дидактичні аспекти адаптації ідей синергетики у зміст освіти; використання їх у моделюванні і прогнозуванні розвитку освітньо-виховних систем; використання в управлінні навчально-виховним процесом. Через синергетику можна досягти більш глибокого розуміння складних френоменів психіки і креативності людини. Вона стане в пригоді для зняття деяких психологічних бар'єрів, зокрема страху перед складними системами, страху перед хаосом, допоможе побачити і відчути красу і подвійність природи, конструктивність і деструктивність хаосу. «Синергетика - це устремління людини в глибини матеріального і духовного світу, шлях до пізнання глибинних пластів Всесвіту», - стверджував академік І. Зязюн [2, с. 451].

Цілком поділяємо висновки, зроблені Л. Ткаченко стосовно того, що з позиції синергетики розвиток особистості $€$ постійним рухом від одного стану системи до іншого, в якому хаос, випадковість, створення/руйнування, проходження точок біфуркації тощо $€$ природними станами системи, що, послідовно змінюючи один одного, вибудовують безперервний ланцюг перетворень [11, с. 18-21].

Не викликає заперечень, що особистість 3 позицій синергетики - складна багаторівнева самоорганізована система. Складність і багаторівневість зумовлена як на фрізико-біологічному, так і духовно психічному рівнях. Оскільки розвиток особистості виступає як постійний саморозвиток і самовизначення системи, це передбачає суб'єкт-суб'єктне управління саморозвитком креативності особистості з урахуванням синергетичних закономірностей.

Вважаємо за доцільне у процесі дослідження проблеми професійної підготовки майбутніх магістрів початкової освіти до інноваційної діяльності використати синергетичний підхід. Слід зазначити, що синергетичний підхід пояснює систему профресійної підготовки як таку, що самоорганізовується. Такими системами у вищій освіті $€$ студент, у нашому випадку це майбутні магістри початкової освіти, викладач, їхній взаємозв'язок тощо. Із позиції такого розуміння синергетичний підхід забезпечує цілісність змісту професійної освіти майбутніх фрахівців освітнього рівня «Магістр» за рахунок фрормування ґрунтовної відкритої системи знань і умінь, які не лише ефективно використовуються у професійній діяльності, але й оперативно перебудовуються та оновлюються відповідно до змін у сучасній науці.

3 урахуванням викладених основних положень синергетичного підходу пропонуємо основні вимоги до професійної підготовки майбутніх магістрів початкової освіти до інноваційної діяльності: процес професійної підготовки має бути відкритою системою, тобто складатися 3 підсистем, між якими відбувається обмін інформацією; необхідно 
збагачувати навчальний процес синергетичними методами навчання, такими як: самоосвіта, стимулююче навчання, нелінійний діалог учасників освітнього процесу, навчання як адаптивна модифікація, які сприятимуть формуванню світоглядних, методологічних і синергетичних знань і умінь; основою сучасної вищої освіти мають стати не стільки навчальні дисципліни, скільки способи мислення та інноваційна діяльність, тобто ЗВО мають створити умови не лише для забезпечення майбутнього фрахівця ґрунтовними професійними знаннями, навичками для фрормування його світогляду на основі сучасної наукової картини світу, а й розвитку самостійного, критичного, творчого мислення, умінь і навичок контролю, прогнозування, своєчасного прийняття обґрунтованих рішень, а головне-сприятисоціальнійсамореалізаціїособистості.

Аналіз наукової літератури із зазначеної проблематики дав змогу виділити основні шляхи реалізації синергетичного підходу у професійній підготовці майбутніх магістрів початкової освіти до інноваційної діяльності: створення єдиного міждисциплінарного простору у закладі вищої освіти; інноваційний тип відносин між усіма учасниками освітнього процесу, що передбачає взаємодію на правах рівності, співробітництва, співтворчості, взаємної допомоги; використання синергетичних методів навчання: самоосвіти, нелінійного діалогу; внесення змін у програми фундаментальних та фрахових дисциплін з використанням основних понять синергетики.

Із викладених позицій випливає розуміння реалізації синергетичного підходу в площині професійної підготовки, зокрема не сорормувати і навіть не виховати, а знайти й підтримати, розвинути професійний потенціал майбутніх педагогів і закласти механізми самовизначення, самореалізації, саморозвитку, адаптації, саморегуляції, самозахисту, самовиховання, що необхідні для інноваційної діяльності.

Висновок. Узагальнюючи сказане вище, можна зробити висновок, що використання синергетичного підходу у професійній підготовці майбутніх магістрів початкової освіти до інноваційної діяльності сприяє збагаченню навчально-виховного процесу діалоговими прийомами і методами педагогічної взаємодії, що інтенсифрікує процес особистісно-профресійного зростання майбутніх педагогів. Діалог думок, мотивів, ціннісних установок молоді та дорослих сприяє формуванню духовно збагаче- ної, морально й емоційно сприятливої атмоссрери у закладах вищої освіти. Водночас синергетичний підхід $€$ міждисциплінарним напрямом наукових досліджень і може слугувати методологічним підґрунтям профресійної підготовки майбутніх магістрів початкової освіти до інноваційної діяльності у закладах вищої освіти.

Перспективи подальших досліджень. Синергетичний підхід не може пояснити абсолютно все, що відбувається на сучасному етапі в освіті та науці. Проте він дає змогу по-новому пояснити окремі моменти динаміки педагогічних систем порівняно з традиційними методами, а також розкрити сутність окремих складників у розвитку педагогічних процесів та явищ.

\section{БІБЛІОГРАФІЧНИЙ СПИСОК:}

1. Всесвітня декларація про вищу освіту для XXI століття: підходи і практичні заходи. URL: http:// euroeducation.org.ua/inshi-programni-dokumenty/ 1vsesvitnya-deklaraciya-pro-vyshchu-osvitu-dlya-hhistolittya-pidhody-i.

2. Зязюн І.А. Філософрія педагогічної дії : монографрія. Черкаси : Вид. від ЧНУ імені Богдана Хмельницького, 2008. 608 с.

3. Кремень В.Г., Ільїн В.В. Синергетика в освіті : контекст людиноцентризму. Київ : Педагогічна думка, 2012. С. 279.

4. Кремень В.Г Інфрормаційно-комунікаційні технології в освіті і фрормування інформаційного суспільства. Інформатика та інфрормаційні технології в навчальних закладах. 2006. № 6. С. 4-9.

5. Кудрявцев И.К., Лебедев С.А. Синергетика как парадигма нелинейности. Вопросы фрилософрии. 2002. № 12. С. 55-63.

6. Національна стратегія розвитку освіти в Україні на 2012-2021 роки : схвалено Указом Президента України від 25 червня 2013 року № 344/2013. URL: http://zakon4.rada.gov.ua/laws/ show/344/2013.

7. Новейший фрилософрский словарь. / Сост. А.А. Грищанов. Минск : Изд. В.М. Скакун, 1998. C. 618.

8. Пригожин И. Философия нестабильности. Вопросы фрилософрии. 1991. № 6. С. 45-57.

9. Прісняков В.Ф. Синергетика. Енциклопедія освіти. / Акад. пед. наук України ; гол. ред. В.Г. Кремень. Київ : Юрінком Інтер, 2008. С. 811-812.

10. Свідзинський А.В. Синергетична концепція культури. Луцьк : Вежа, 2008. 696 с.

11. Ткаченко Л.І. Синергетичний підхід у педагогіці : нова парадигма. Освіта та розвиток обдарованої особистості. № 10 (17). 2013. С. 18-21.

12. Хакен Г. Синергетика. Москва: Мир, 1980. 406 с. 